\title{
A Small Plasmid Isolated from an Avirulent Mutant of Pseudomonas solanacearum
}

\author{
Hideaki Negishi*, Tetsuji YAMAdA**, Tomonori ShIRAISHI**, \\ Hachiro OKU** and Hiroshi TANAKA*
}

Key words: Pseudomonas solanacearum, plasmid.

Pseudomonas solanacearum E. F. Smith, a causal agent of bacterial wilt (mainly to solanaceous plants), is one of the most destructive plant pathogens in the world. Genes related to the virulence of $P$. solanacearum have been elucidated by several groups. Boucher et al. ${ }^{1)}$ suggested that most virulent genes were clustered in a megaplasmid. $\mathrm{Xu}$ et al. ${ }^{2)}$ suggested that numerous genes were involved in virulence by transposon mutagenesis.

Although it is well known that $\boldsymbol{P}$. solanacearum loses virulence spontaneously under certain laboratory conditions ${ }^{3)}$, genes governing and/or controlling avirulence have not been fully elucidated. Currier and Morgan ${ }^{4)}$, and Morales and Sequeira ${ }^{5)}$ reported that spontaneous avirulent mutants showed no detectable change in plasmid number and the size compared to the parental strains.

A spontaneous avirulent mutant, M4S, which was attempted for use in the biological control of bacterial wilt of tobacco, was isolated from still culture of virulent strain $P$. solanacearum $\mathrm{U}^{\left.-7^{6}\right)}$.

This paper describes the structure of the plasmid containing only in a spontaneous avirulent mutant, M4S, and discusses the origin of this plasmid.

$P$. solanacearum, M4S and U-7, described above were routinely grown on Kelman's TZC medium $^{3)}$ at $30 \mathrm{C}$ for 3 days and stored in sterilized distilled water at room temperature.

Plasmids were extracted from the bacterial cells by the method as described by Comai and Kosuge $\left.^{7}\right)$ and fractionated by $0.7 \%$ agarose gel electrophoresis in TBE buffer ( $0.089 \mathrm{M}$ Trisbase, $0.089 \mathrm{M}$ boric acid, $0.002 \mathrm{M}$ EDTA). The presence of plasmid DNA ( $c a .6 .6 \mathrm{kbp})$ was detected only in M4S (Fig. 1A, lane 2) but not in U-7 (data not shown). This plasmid was designated as pJTPS1 and purified by isopycnic centrifugation in $\mathrm{CsCl} /$ ethidium bromide as described $^{8}$. By this method, the megaplasmids, which were detected in several strains of $P$. solanacearum by the modified Eckhardt procedure ${ }^{9,10)}$, were not detected.

The restriction map of pJTPS1 was determined by using various restriction endonucleases.

* Japan Tobacco Inc., Applied Plant Research Laboratory, Yokohama Center, 6-2 Umegaoka, Midori-ku, Yokohama 227, Japan日本たばこ産業 (稹物開発研究所横浜センター

** Laboratory of Plant Pathology, College of Agriculture, Okayama University, 1-1-1 Tsushimanaka, Okayama 700, Japan 岡山大学農学部

1) Boucher, C., Martinel, A., Barberis, P., Alloing, G. and Zischek, C. (1986). Mol. Gen. Genet. 205: 270-275. 2) Xu, P., Leong, S. and Sequeira, L. (1988). J. Bacteriol. 70: 617-622. 3) Kelman, A. (1954). Phytopathology 44: 693-695. 4) Currier, T.C. and Morgan, M.K. (1981). Proc. Fifth Int. Conf. on Plant Pathogenic Bacteria. CIAT, Cali, Colombia. pp. 420-425. 5) Morales, V.M. and Sequeira, L. (1985). Phytopathology 75: 767-771. 6) Tanaka, H. (1985). Bull. Utsunomiya Tob. Expt. Sta. 21: 1-66. 7) Comai, L. and Kosuge, T. (1982). J. Bacteriol. 149: 40-46. 8) Maniatis, T., Fritsch, E.F. and Sambrook, J. (1982). Molecular Cloning: a Laboratory Manual. Cold Spring Harbor Laboratory, Cold 'Spring Harbor, New York. 9) Eckhardt, T. (1978). Plasmid 1: 584-588. 10) Rosenberg, C., Casse-Delbart, F., Dusha, I., David, M. and Boucher, C. (1982). J. Bacteriol. 150: $402-406$. 


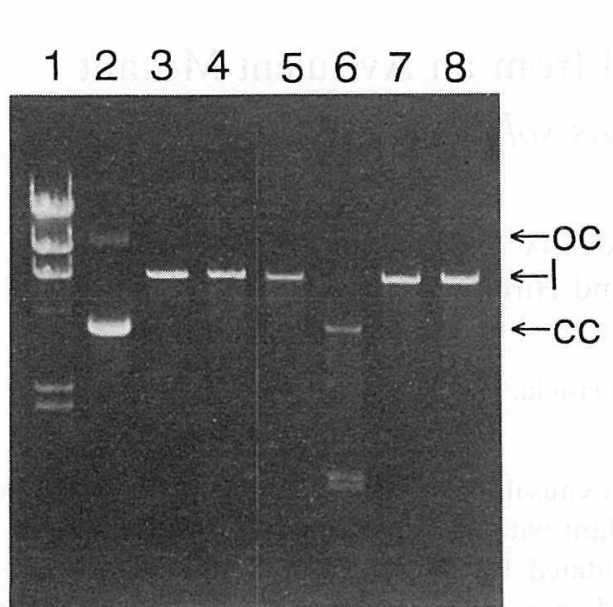

A

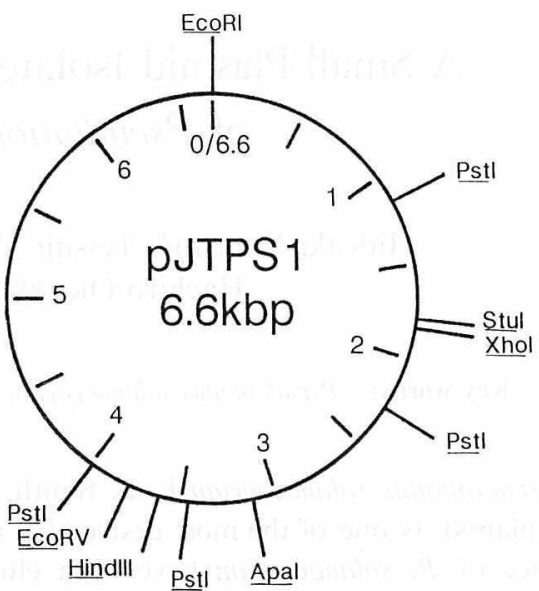

B

Fig. 1. Restriction endonuclease cleavage analysis of plasmid pJTPS1 and the restriction map. (A) Restriction endonuclease cleavage analysis. Lane 1: lambda DNA digested with HindIII (size marker), lane 2: undigested pJTPS1, lane 3-8: pJTPS1 digested by restriction enzymes, with ApaI (lane 3), EcoRI (lane 4), HindIII (lane 5), Pst I (lane 6), StuI (lane 7), and XhoI (lane 8), respectively. Position of closed circular (cc), linear (1), and open circular (oc) forms are indicated by arrows. (B) Restriction map of pJTPS1.

The plasmid pJTPS1 was digested with various restriction endonucleases and the reaction products were subjected to $0.7 \%$ agarose gel electrophoresis. It was found that the plasmid carries a single unique site for ApaI, EcoRI, EcoRV, HindIII, StuI and XhoI (obtained from Nippon Gene Inc. and Takara Inc.) and quadruple sites for Pst I (Fig. 1A). Double and triple digestion of the plasmid with these restriction endonucleases were performed and the reaction products were fractionated by $0.7,1.2$, or $2.0 \%$ agarose gel electrophoresis (data not shown). We derived a restriction map of pJTPS1 as shown in Fig. 1B.

To investigate the origin of pJTPS1, Southern blot hybridization analysis of the total DNA isolated from U-7 with pJTPS1 was performed. pJTPS1 digested with HindIII was used as a hybridization probe. The total genomic DNA of U-7 was isolated by the procedure described by $\mathrm{Xu}$ et $a{ }^{2}{ }^{2}$ except that isopycnic centrifugation in $\mathrm{CsCl} /$ ethidium bromide was omitted. After treatment with RNase I (Sigma), $60 \mu \mathrm{g}$ of the total DNA was digested with EcoRI, HindIII and $P s t \mathrm{I}$, respectively, and subjected to electrophoresis in a $0.7 \%$ agarose gel in TBE buffer. For DNA labeling, blotting and DNA hybridization, ECL ${ }^{\mathrm{TM}}$ gene detection system (Amersham Inc.) was used according to the manufacturer's specification. At least flve PstI fragments hybridizing to the labeled probe were observed (Fig. 2, lane B-2) and three bands positioned at $3.8,1.1$ and $0.6 \mathrm{kpb}$, respectively, were identical to the Pst I fragments of pJTPS1. Two bands hybridizing at the positions about 6.2 and $4.9 \mathrm{kbp}$ with EcoRI digestion and two bands hybridizing at the position larger than $20 \mathrm{kbp}$ with HindIII digestion were observed (Fig. 2, lane B-4, $\mathrm{B}-3$, respectively). These results suggest that pJTPS1 is genome or megaplasmid born and possibly integrated into a genome or megaplasmid linearly with a cut at a certain position of 1.2 kbp Pst I fragment including ApaI site (see Fig. 1B). By the comparison of Pst I fragment hybridized to the labeled probe in U-7's DNA with the given amounts of pJTPS1 (Fig. 2, lane $2,5,6,7$ and 8), and by the assumption that the size of genomic DNA of $P$. solanacearum is approximately $5 \times 10^{6} \mathrm{bp}$, the homologous gene(s) to pJTPS1 existing in U-7 was estimated to be a single copy.

Currier and Morgan $^{4}$ and Morales and Sequeira ${ }^{5)}$ reported that spontaneous avirulent 


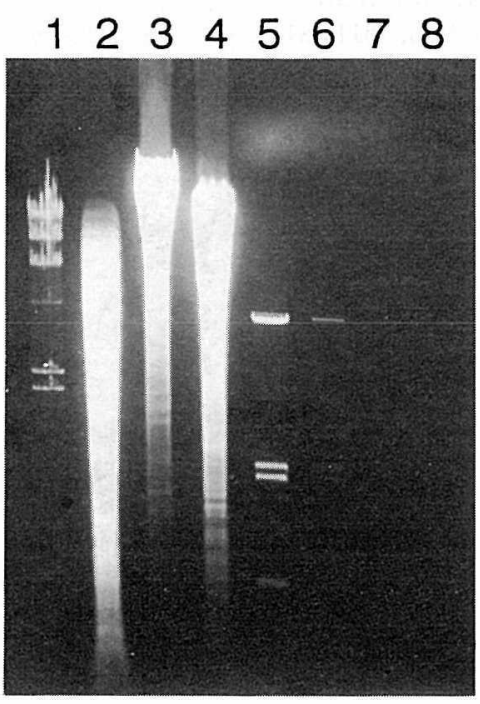

A

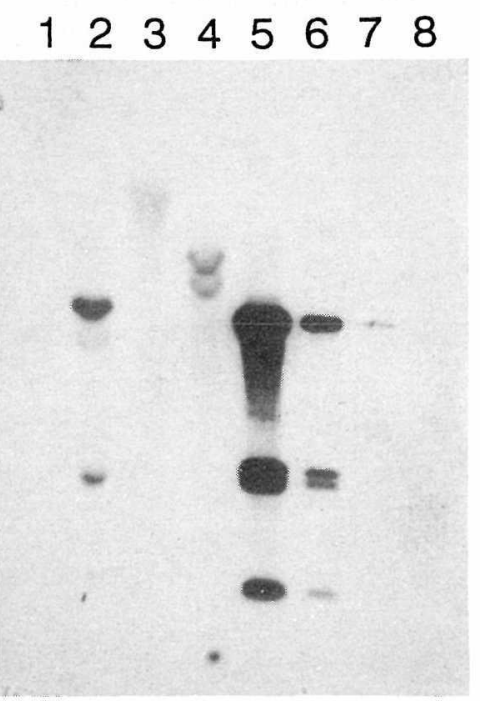

B

Fig. 2. Southern blot hybridization analysis of the total DNA isolated from U-7 probed with HindIII-digests of pJTPS1. (A) The total DNA was electrophoresed in $0.7 \%$ agarose and stained with ethidium bromide. (A) Lane 1: lambda DNA digested with HindIII (size marker), lane 2-4: total DNA isolated from U-7 digested with restriction enzymes, lane 2: Pst I, lane 3: HindIII and lane 4: EcoRI, respectively. Lane 5-8: threshold amount of pJTPS1 digested with Pst I, lane 5: $500 \mathrm{ng}$, lane 6: $50 \mathrm{ng}$, lane 7: $5 \mathrm{ng}$ and lane 8: $0.5 \mathrm{ng}$. (B) Hybridization of the total DNA with ECL TM (Amersham, Inc.)labeled pJTPS1. Lanes correspond to (A).

mutants of $P$. solanacearum harbored the same plasmid(s) as the parental strain without detectable changes in size. Furthermore, a small plasmid, like pJTPS1, was not detected in an avirulent mutant strain of $P$. solanacearum $\mathrm{OM} 2^{11)}$ or its parental strain Ps48 by this method (data not shown).

The fact that pJTPS1 exists only in an avirulent mutant, M4S, but not in the parental virulent strain of $P$. solanacearum, U-7, may represent a unique finding in plant pathogenic bacteria, although there are some reports that certain plasmid-like DNA or double-stranded RNA are possibly involved in the hypovirulence of the fungal plant pathogens ${ }^{12}$. Furthermore, it appears that pJTPS1 may be derived from genome or megaplasmid.

It is not clear whether the presence of pJTPS1 is correlated to the mutation from virulence to avirulence. Studies are under way to determine whether pJTPS1 is involved in the loss of virulence of $P$. solanacearum by direct transformation of pJTPS1 into the virulent strain, U-7.

\section{和 文 摘 要}

\footnotetext{
根岸秀明・山田哲治 - 白石友紀 - 奥 八郎 - 田中 博 : Pseudomonas solanacearum の非病原性突然変異 株から分離されたプラスミド

Pseudomonas solanacearum の自然発生の非病原性突然変異株, M4S から約 $6.6 \mathrm{kbp}$ の環状 2 重鎖のプラ スミド DNA, pJTPS1 を分離した。pJTPS1 は M4S の親株である病原性菌, U-7 からは検出されなかった。
}

11) Hara, H. and Ono, K. (1989). Ann. Phytopath. Soc. Japan 55: 511. 12) Buck, K.W. (1986). Fungal Virology. CRC Press, Inc., Boca Raton. pp. 1-84. 
このプラスミドは, ApaI, EcoRI, EcoRV, HindIII, Pst I, StuI, XhoI などの制限酵素認識部位をもっていた。 U-7 の全 DNA とのハイブリダイゼーション分析の結果から, pJTPS1 はゲノムまたはメガプラスミド由来 であろらと推測された。

(Received June 18, 1990) 